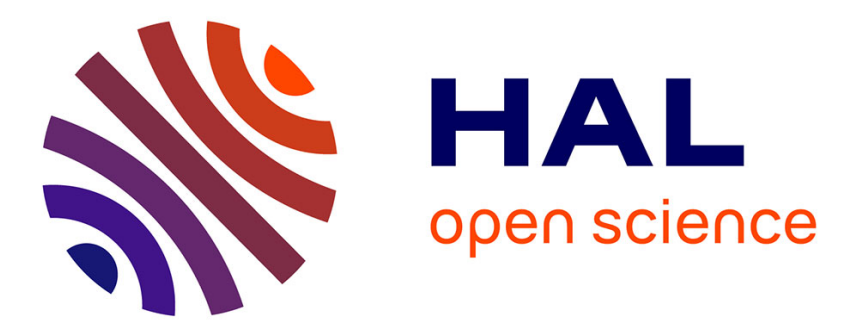

\title{
Modification of the gravitropic response of seedling roots of rapeseed (Brassica napus) transformed by Agrobacterium rhizogenes A4
}

\author{
Valérie Legué, F. Vilaine, M. Tepfer, G. Perbal
}

\section{- To cite this version:}

Valérie Legué, F. Vilaine, M. Tepfer, G. Perbal. Modification of the gravitropic response of seedling roots of rapeseed (Brassica napus) transformed by Agrobacterium rhizogenes A4. Physiologia Plantarum, 1994, 91 (4), pp.559 - 566. hal-01706284

\author{
HAL Id: hal-01706284 \\ https://hal.uca.fr/hal-01706284
}

Submitted on 14 Feb 2019

HAL is a multi-disciplinary open access archive for the deposit and dissemination of scientific research documents, whether they are published or not. The documents may come from teaching and research institutions in France or abroad, or from public or private research centers.
L'archive ouverte pluridisciplinaire HAL, est destinée au dépôt et à la diffusion de documents scientifiques de niveau recherche, publiés ou non, émanant des établissements d'enseignement et de recherche français ou étrangers, des laboratoires publics ou privés. 


\title{
Modification of the gravitropic response of seedling roots of rapeseed (Brassica napus) transformed by Agrobacterium rhizogenes A4
}

\author{
V. Legué, F. Vilaine, M. Tepfer and G. Perbal
}

Lequé, V., Vilaine. F., Tepfer, M. and Perbal, G. 1994. Modification of the gravitropic response of seedling roots of rapeseed (Brassica napus) transformed by Agrobacterium rhizogenes A4. - Physiol. Plant. 91: 559-566.

We have examined the grow th and gravitropic response of seedling roots of rapeseed (Brassica napas. CrGC5-1) transformed by Agrobacterium rhizogenes A4, in order to evaluate if this could constitute a new model system for the study of grawitropism. The transformed clone chosen for study had integrated full-length TL-and TR-DNA from pRi (the root inducing plasmid), and thus included all of the agrobacterial genes potentially involved in the modified phenotype of transformed plants. In the vertical position. the growth rate of transformed roots was higher than controls. During $24 \mathrm{~h}$ of continuous stimulation, the optimal angle for gravitropic bending in normal roots was $135^{\circ}$ (with respect to the gravity axis). with decreasing response at $90^{\circ}$ and $45^{\circ}$. For transformed roots, slight curvature developed at $45^{\circ}$ and at $90^{\circ}$. and stronger curvature was observed at $135^{\circ}$. though transformed root tips never reached the vertical position. The minimum stimulation time necessary to elicit a response (presentation time) was also determined: it was significantly shorter in normal roots $(80 \mathrm{~s})$ than in transformed ones $(120 \mathrm{~s})$. The results show that pRi transformed roots are less sensitive to gravity than normal roots.

Kev words - Agrobacterium rhi-ogenes, Brassica napus, gravitropism. gravity, pRi T-DNA, rapeseed, transformed seedlings.

V. Legué rcorresponding author) and G. Perbal. Univ. Plerre et Marie Curie Laboratorre de Cvologie Expérimentale et Morphogenèse Végétale Bât N2. F-75252 Paris Cedex 05, France: F. Vilaine and M. Tepfer. INRA-Cenire de Versailles, Laboratoire de Biologie Cellulaire, F-78026 Versailles Cedex. France.

\section{Introduction}

Root gravitropism is the result of differential growth of the lower and upper sides of roots that are not vertically oriented relative to the gravitational field (Jackson and Barlow 1981, Barlow and Hofer 1982, Darbelley and Perbal 1984). Reorientation may also result in changes in the overall rate of root elongation relative to vertical roots (Firn and Digby 1980, Pilet and Ney 1981), and growth asymmetry varies during the gravitropic response (Selker and Sievers 1987, Ishikawa et al. 1991, Zieschang and Sievers 1991). According to the Cholodny-Went theory (Cholodny 1928, Went and Thimann 1937), indoleacetic acid (IAA) which could be the message is transmitted from the cap toward the response zone of the root (Shaw and Wilkins 1973, Rivier and Pilet 1974, Young et al. 1990). It is proposed that lateral IAA transport will cause unequal rates of cell elongation, leading to curvature. Recent studies of growth kinetics during root gravitropism suggest that asymmetry of growth is related both to changes in auxin sensitivity and to redistribution of this hormone (for review see Evans 1991).

Mutants with modified gravitropism have been used to study certain steps of this growth response. Detailed comparative studies of the gravireactivity in a mutant and a wild-type of Arabidopsis thaliana, showed that starch grains are necessary for full sensitivity (Kiss et al. 1989 , Saether and Iversen 1991). In ultrastructural studies of

Received 19 November, 1993; revised 4 March, 1994 
statocytes of the ageotropum pea mutant, the principal difference observed by Olsen and Iversen (1980a,b) was in the distribution of rough endoplasmic reticulum. In other studies, auxin-resistant A. thaliana showed no significant graviresponse at any angle of stimulation tested (Mirza et al. 1984).

Plants transformed by Agrobacterium whizogenes also represent a potential tool for improved understanding of gravitropism. A. rhizogenes first attracted attention because it induces modified growth characteristics of roots, which grow in vitro without exogenous phytohormones and from which plants displaying a strikingly modified phenotype can be regenerated (Ackermann 1977). The root-inducing plasmid ( $\mathrm{pRi}$ ) of A. rhizogenes bears one or two DNA regions (T-DNA) that can be transferred to the plant genome (Chilton et al. 1982, Spano et al. 1982). The T-DNAs include genes that profoundly modify plant development (Tepfer 1984). The well studied agropine-type Ri plasmid harbors two distinct T-regions. TL and TR (De Paolis et al. 1985. White et al. 1985). The TR-DNA contains auxin biosynthetic genes which in some cases affect root development (Amselem and Tepfer 1992), and the TL-DNA includes three genes ( $\operatorname{rol} A, B$ and $C$ ) involved both in the induction of transformed roots (White et al. 1985) and in the determination of the modified phenotype of plants regenerated from transformed roots (Jouanin et al. 1987, Schmülling et al. 1988). In regenerated plants, the root system is also highly modified, such that roots are highly branched and tend to grow at the soil surface (Tepfer 1984). Differences in apparent gravitropic behavior have also been noted in roots induced by A. rhizogenes on whole plants or on various explants (White et al. 1985, Spano et al. 1987). Capone et al. (1989) have shown in vitro that carrot roots containing only rolB did not respond to gravity, while roots transformed with rol $(A+B+C)$ displayed normal gravitropic behavior.

However, previously described systems for studying gravitropism of transformed roots have serious drawbacks. Non-transformed roots grow poorly in vitro in the absence of exogenous hormones, making comparisons with transformed roots difficult. In species like tobacco, roots of non-transformed plants have a weak gravitropic response, and transformed roots branch very soon after germination, again making comparisons diffïcult (M. Tepfer, unpublished results). We have studied root gravitropism in seedlings of rapeseed (Brassica napus, CrGC5-1) transformed by A. rhizogenes A4. We describe here the basic parameters of the growth and gravitropic response of these roots, and show that pRi T-DNA genes do profoundly modify the root graviresponse. This is the first system that allows studies of gravitropism in transformed roots under conditions similar to those used in the numerous studies of gravitropic behavior of non-transformed seedling roots.

Abbreviations - $\mathrm{pRi}$, root inducing plasmid; SDS, sodium dodecyl sulfate; SSC, saline sodium citrate; T-DNA. DNA trans- ferred from pRi to the plant genome; TLDNA, leftward TDNA: TR-DNA, rightward T-DNA.

\section{Materials and methods}

\section{Induction of transformed roots and regeneration of transgenic plants}

General procedures for plant transformation with $A$. rhizogenes were as described previously (Tepfer and CasseDelbart 1987). Briefly, rapid cycling rapeseed plants (Brassica napus, CrGC5-1; Williams and Hill 1980) were grown in the greenhouse until the appearance of the first flower buds. Stem segments were surface-sterilized, placed with their basal ends upwards in MS medium (Murashige and Skoog 1962), in which the nitrogen (both $\mathrm{NH}_{4} \mathrm{NO}_{3}$ and $\mathrm{KNO}_{3}$ ) content was reduced by $80 \%$ (MS $\mathrm{N} / 5$ ), and inoculated with a fresh culture of $A$. rhizogenes A4. After approximately two weeks, roots were removed from the explant, decontaminated by two passages in antibiotic-containing medium, and further cultured in MS N/5 medium. Plants were regenerated from transformed roots exactly as described for the rapeseed $\mathrm{cv}$. Brutor by Guerche et al. (1987). Homozygous R2 seedlings were obtained by selfing transformed plants through two successive generations.

\section{Southern blot hybridization}

Genomic DNA was extracted from leaves of homozygous R2 plants according to Dellaporta et al. (1983). DNA $(10 \mu g)$ was hydrolysed with appropriate restriction enzymes. After electrophoresis on $0.8 \%$ agarose gels, DNA was transferred to Pall Biodyne B membrane in 0.4 $M \mathrm{NaOH}$ for $4 \mathrm{~h}$ and hybridized at $42^{\circ} \mathrm{C}$ with a randomprimed ${ }^{32}$ P-labelled probe (Feinberg and Vogelstein 1983 ) in the buffer described by Church and Gilbert (1984). After 24 h hybridization, the membranes were washed for $0.5 \mathrm{~h}$ in $2 \times \mathrm{SSC}$ at room temperature, followed by $0.5 \mathrm{~h}$ in $2 \times \mathrm{SSC}+0.1 \% \mathrm{SDS}$ at $50^{\circ} \mathrm{C}$ and twice $0.5 \mathrm{~h}$ in $0.5 \times \mathrm{SSC}+0.1 \% \mathrm{SDS}$ at $50^{\circ} \mathrm{C}$.

\section{Culture conditions}

Normal and homozygous (R2 and R3) transformed seeds were hydrated on wet filter paper in petri dishes at $25^{\circ} \mathrm{C}$ in the dark. Controls germinated after $17 \mathrm{~h}$ imbibition, while transformed seeds germinated after $14 \mathrm{~h}$. At this stage, young seedlings selected for uniformity were placed on the surface of $0.8 \%(\mathrm{w} / \mathrm{v})$ water agar in $12 \mathrm{~cm}$ petri dishes with radicles pointing downward. The petri dishes were sealed with Parafilm and were maintained vertically under constant light from one white fluorescent tube (Aric, $8 \mathrm{~W}, 1.5-2.0 \mathrm{~W} \mathrm{~m}^{-2}$ ) fitted with a gelatin Kodak number 12 filter, which absorbs blue light, making photography possible without inducing a phototropic response (Klemmer and Schneider 1979). 
A

B

$\begin{array}{lll}1 & 2 & 3\end{array}$

12
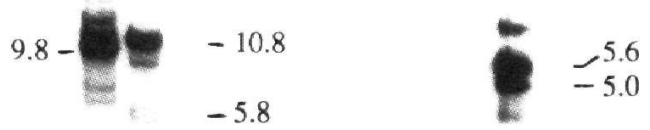

$1.6--$

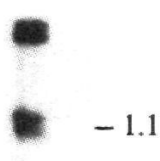

$-0.6$

Fig. I. Southern analysis of TL- and TR-DNA in transformed rapeseed clone Rd (3). Genomic DNA was digested with $\mathrm{BamHI}$ (Panel A. lane I) K Knl (panel A. lanes 2 and 3 ) or Ball (panel B. lines 1 and 2 ). Lanes $I$ and 2 of panel $A$, and lane $I$ of panel B are Rd (3) DNA: lane 3 of panel A and lane 2 of panel B atre non-transformed control rapeseed DNA. Blots were probed with either pLJ/ covering the TL-region (A) or pLJ85, covering the TR-region (B). The size of internal fragments is indicated, other bands are presumed to represent border fragments.

\section{Root growth and gravitropism experiments}

To study root growth, control and transformed seedlings were kept in the vertical position for $30 \mathrm{~h}$. Root growth was recorded photographically at 2 -h intervals, with a 35 $\mathrm{mm}$ camera fitted with a macro lens. Root length was determined from photographic prints using a video camera and specific image analysis programs (available from the authors upon request). To study gravitropic behavior of control and transformed roots. seedlings were maintained vertically during the first $23 \mathrm{~h}$. At that time, any roots that were not vertical were re-orjented, 1 h after which the roots were gravistimulated at various angles $\left(45^{\circ} .90^{\circ}\right.$ or $135^{\circ}$ with respect to the vertical axis) by re-orienting the petri dishes. The kinetics of the gravitropic curvature was recorded photographically, every $15 \mathrm{~min}$ for $1 \mathrm{~h}$ and then every hour for $23 \mathrm{~h}$. The angle of curvature was determined by calculating the orientation of the first $\mathrm{mm}$ of the root tip with respect to its position at zero time of stimulation. Curvature and elongation were measured from photographic prints with a specific image analysis program

\section{Presentation time}

To determine the presentation time, normal and transformed roots. grown vertically for $24 \mathrm{~h}$ under the conditions described above. were stimulated at $135^{\circ}$ for brief time periods $(2,3,5$ or $10 \mathrm{~min})$. They were then rapidly
Fig. 2. Structure of T-DNA in transformed rapeseed clone Rd (3). For the TL-DNA (above) and the TR-DNA (below) are shown isuccessively from top to bottom): sequence coordinates, deduced open reading frames and corresponding functional loci where known, appropriate restriction maps (fragment size indicated), the usual extent of TL- and TR-DNA. (arrow), the extent of TL- and TR-DNA in clone Rd (3) as determined by the DNA blot hybridizations shown in Fig. 1 (internal fragments are indicated by a thick line and border fragments by thin lines).

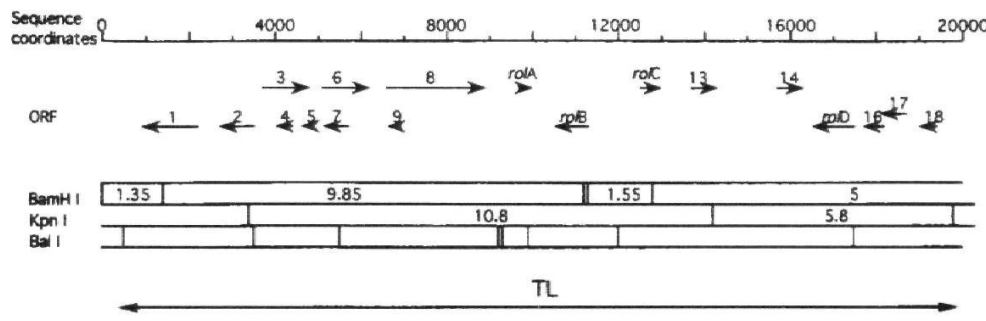

$\mathbf{R D}(3)$

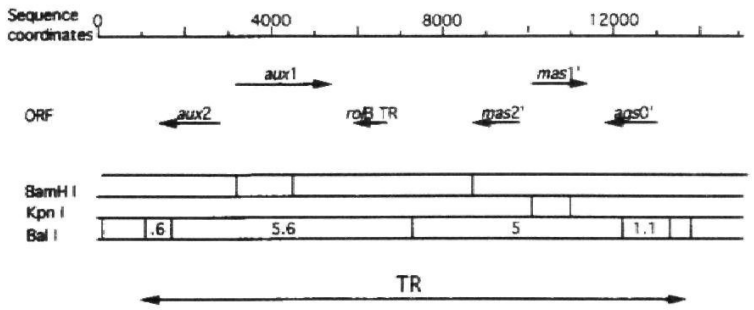

$\operatorname{RO}(3)$ 


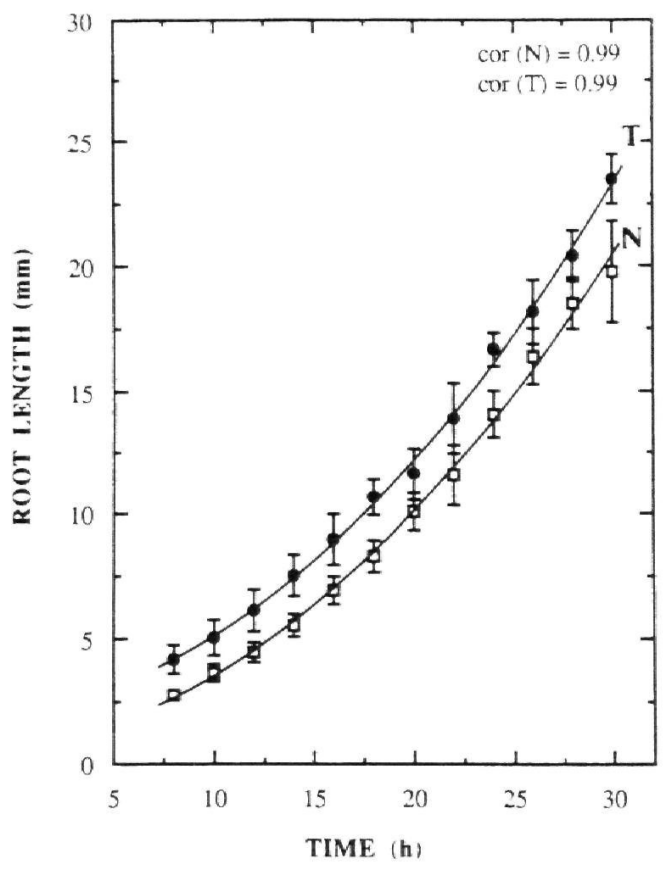

Fig. 3. Growth of normal and transformed roots in the vertical position. The length of normal $(N)$ and transformed $(T)$ roots was determined for the period 8 to $30 \mathrm{~h}$ after germination. Vertical bars represent confidence intervals at $P=0.05$ in $>30$ ). Each value represents $42(\mathrm{~N})$ and 48 (T) seedlings. Growth data were fitted to a second order polynomial. Equations: $y=0.02 \mathrm{x}^{2}$ $-0.16 x+2.83(\mathrm{~N})$ and $y=0.02 x^{2}+0.01 x+2.26(\mathrm{~T})$

transferred to a clinostat that rotated samples around the horizontal axis for $1.5 \mathrm{~h}$ (centrifugal acceleration did not exceed $1 \times 10^{-4} \mathrm{~g}$, Driss-Ecole et al. 1994). The axis of the roots was parallel to the axis of rotation of the clinostat. Seedlings were photographed after $1.5 \mathrm{~h}$ for measurement of curvature as above.

Tab. 1. Growth rates $\left(\mathrm{mm} \mathrm{h}^{-1}\right)$ of normal (N) and transformed (T) roots either maintained in the vertical position or gravistimulated at $90^{\circ}$ or $135^{\circ}$. Experiments were performed between 24 and $26 \mathrm{~h}$ of growth. Average values $(15 \mathrm{~N}$ or $17 \mathrm{~T}$ roots) are followed by confidence intervals at $P=0.05$. The averages were compared with Student's $t$-test: NS, not significant at $P=0.05$; $\mathrm{S}$, significant at $P=0.05$

\begin{tabular}{lcccc}
\hline Experiment & Position & Normal roots & & Transformed roots \\
\hline 1 & $\left(0^{\circ}\right)$ & $0.80 \pm 0.17$ & $\mathrm{~S}$ & $1.19 \pm 0.13$ \\
$\mathrm{NS}$ & & $\mathrm{S}$ \\
& $90^{\circ}$ & $0.94 \pm 0.09$ & NS & $0.98 \pm 0.18$ \\
& $\left(0^{\circ}\right)$ & $1.08 \pm 0.18$ & $\mathrm{~S}$ & $1.34 \pm 0.18$ \\
& $135^{\circ}$ & $0.70 \pm 0.25$ & $\mathrm{~S}$ & $1.11 \pm 0.26$ \\
\hline
\end{tabular}

\section{Results}

Molecular analysis of transformed rapeseed

Genomic DNA was hydrolyzed by BamHI or $K p n I$ and hybridized to ${ }^{32} \mathrm{P}$-labelled $\mathrm{pLJ} 1 \mathrm{DNA}$, a probe covering the entire TL-DNA (Jouanin 1984). Approximately 4 copies of full-length TL-DNA had been integrated, as estimated from the number of border fragments (Fig. 1). Similarly, the extent and copy number of TR-DNA were estimated from hybridization of Ball-digested plant DNA with labelled pLJ85, which covers the entire TR-region (Jouanin 1984). Approximately 2 copies of full-length TR-DNA were integrated, including the aux genes, which may be responsible for auxin biosynthesis in transformed tissues (Fig. 1). Functionality of the aux2 gene was confirmed by sensitivity of seedlings to naphthalene acetamide (M. Tepfer, unpublished results). The extent of the transferred DNA in the clone studied, designated Rd(3), is represented in Fig. 2. This clone was considered appropriate for determining to what extent the gravitropic response is modified in pRi-transformed seedlings, since full-length TL- and TR-DNA was transferred, including all the genes known to affect plant development.

\section{Root growth in the vertical position}

Elongation of normal and transformed roots maintained vertically was followed from the 8 th to the 30 th hour after depositing on the agar surface (Fig. 3). The length of both normal and transformed roots fitted a second order polynomial function. Normal and transformed roots differed significantly in length during the first $30 \mathrm{~h}$ of seedling growth. At the time chosen for gravistimulation, transformed roots grew at a significantly higher rate than control roots (Tab. 1), and their average lengths were 15.3 and $14.0 \mathrm{~mm}$, respectively.

\section{Gravitropic behavior}

After $24 \mathrm{~h}$ of growth in the vertical position under standard conditions, normal and transformed seedlings were oriented at different angles $\left(45^{\circ}, 90^{\circ}\right.$ or $135^{\circ}$ relative to the vertical axis) and their growth and curvature observed at $2 \mathrm{~h}$ and $6 \mathrm{~h}$ (Fig. 4). The kinetics of curvature of roots stimulated at different angles are shown in Fig. 5. At all angles of stimulation, the curvature of roots of normal and transformed seedlings could be divided into 3 arbitrary phases (I, II and III). These phases are indicated in Fig. 5 (for phases II and III) and Fig. 6 (for phases I and II). Phase I represents the latent period, which, for each angle of stimulation, was calculated by extrapolating to the abscissa the initial phase of curvature designated phase II in Figs. 4 and 5. At a given angle of stimulation, both normal and transformed roots began to curve after the same latent time (Fig. 6), but the latent time varied with each angle of stimulation. Normal and transformed roots stimulated at $45^{\circ}$ curved slowly and at the same rate during phase II (Fig. 6A, about $0.16^{\circ} \mathrm{min}^{-1}$ ). During 
NORMAL ROOTS

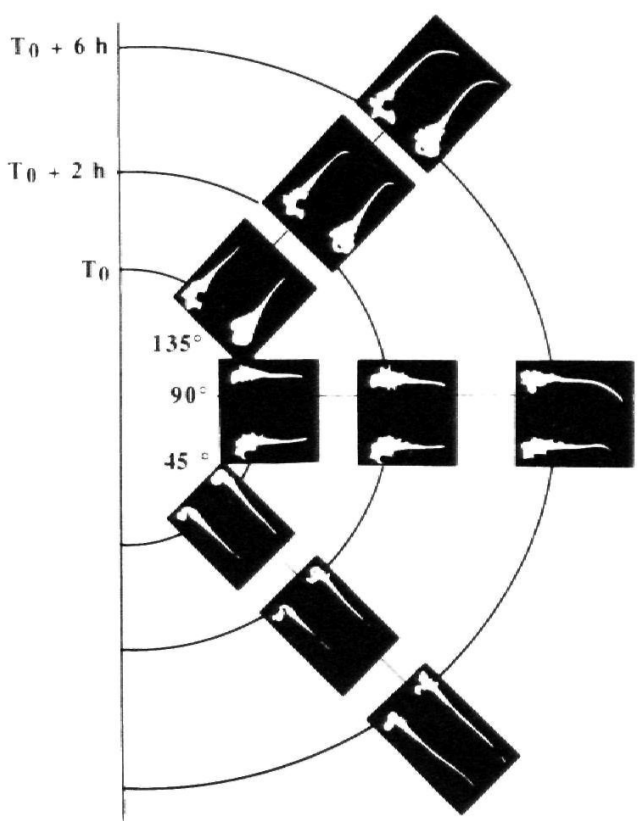

TRANSFORMED ROOTS

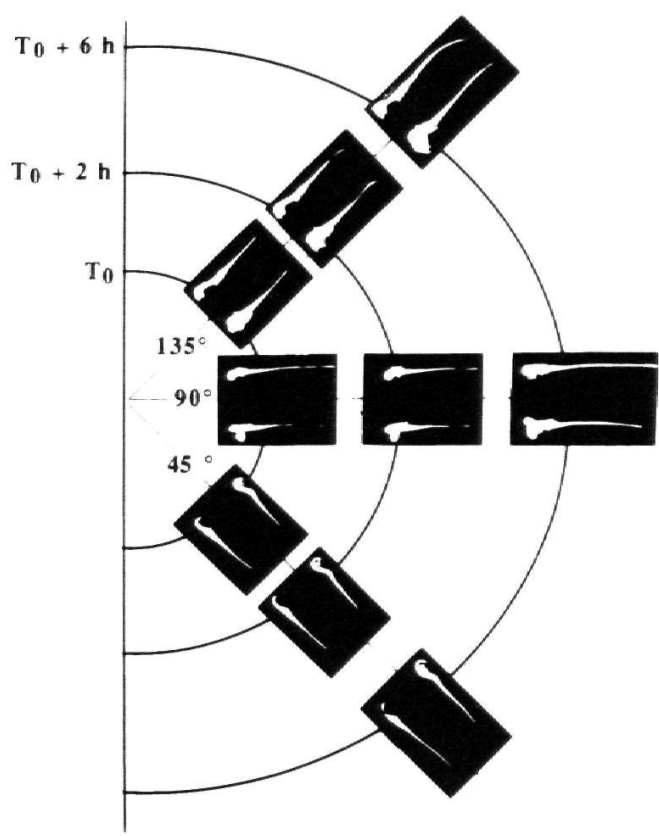

Fig. 4. The successive stages of the graviresponse of normal (N) and transformed (T) roots stimulated at $45^{\circ}, 90^{\circ}$ and $135^{\circ}$. Entire seedlings are shown at the start of stimulation $\left(\mathrm{T}_{4}\right)$ and after 2 and 4 h stimulation.

phase III, the rate of curvature of normal roots gradually decreased as their orientation progressively reached the gravity axis (Fig. 5A), whereas transformed roots did not continue curving.

After stimulation at $90^{\circ}$ (Fig. 5B), the curvature rate of normal roots was high for $1 \mathrm{~h}\left(0.35^{\circ} \mathrm{min}^{-1}\right.$, phase II in Fig. 6B), while transformed roots curved significantly less rapidly $\left(0.07^{\circ} \mathrm{min}^{-1}\right)$. After $18 \mathrm{~h}$ stimulation, the normal roots reached a final angle corresponding to the vertical position, while the transformed roots continued to grow at a constant angle, which did not exceed $20^{\circ}$ with respect to the horizontal.

The root tips of normal seedlings stimulated at $135^{\circ}$ (Fig. 5C) rapidly reached the horizontal position, with a curvature rate of $0.93^{\circ} \mathrm{min}^{-1}$ (Fig. 6C), and continued to bend toward the vertical position, which they had not reached even after $24 \mathrm{~h}$ of stimulation. Transformed roots stimulated at $135^{\circ}$ curved rapidly during the first hour of stimulation $\left(0.35^{\circ} \mathrm{min}^{-1}\right.$, Fig. $\left.6 \mathrm{C}\right)$, and reached a final angle (about $45^{\circ}$ with respect to the angle of stimulation) that caused the roots to be oriented in the horizontal position (Fig. 5C).

\section{Growth rate of stimulated roots}

The growth rate of normal and transformed roots was determined for both types of roots maintained in the vertical position (between 24 and $26 \mathrm{~h}$ ) and during the first $2 \mathrm{~h}$ of stimulation at $90^{\circ}$ or $135^{\circ}$ (during phase II of curvature, Tab. 1). When normal roots were stimulated horizontally $\left(90^{\circ}\right)$, the growth rate did not change significantly during the first $2 \mathrm{~h}$. However, in transformed roots, the elongation rate was significantly lower in stimulated roots than in the vertical ones. Stimulation at $135^{\circ}$ induced an inhibition of growth during the first $2 \mathrm{~h}$ in both normal and transformed roots.

\section{Presentation time}

Transformed roots curved only slowly during the first 1.5 h of horizontal stimulation but responded significantly to stimulation of $135^{\circ}$ (Fig. 5). We decided to determine the presentation time by giving roots a brief stimulation at $135^{\circ}$, which sufficed to induce a curvature that developed during subsequent rotation on a clinostat for $1.5 \mathrm{~h}$. The angle of curvature was plotted as a function of the logarithm of the stimulation time (Fig. 7). The presentation time, which represents the threshold stimulus for gravitropic response, was calculated by putting $y=0$ in the regression equation (Johnsson and Pickard 1979). The values obtained were $80 \mathrm{~s}$ for normal and $120 \mathrm{~s}$ for transformed roots. The presentation time for transformed roots is thus $50 \%$ longer than in normal ones. 


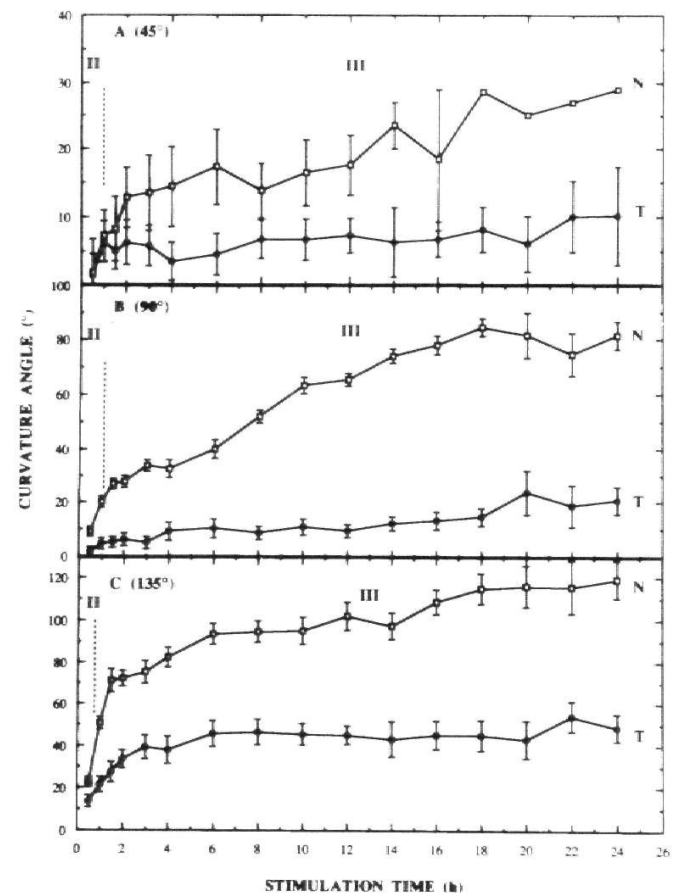

Fig. 5. Kinetics of curvature of normal (N) and transformed (T) roots maintained for 24 h at (A) $45^{\circ}$. (B) $90^{\circ}$ and (C) $135^{\circ}$ with respect to the vertical axis. Vertical bars represent confidence intervals at $P=0.05(\mathrm{n}>30)$. Each value represents more than 40 roots. with 3 replicates in each experiment. II and III indicate different phases of the root graviresponse.

\section{Discussion}

The gravitropic reaction of pRi-transformed roots is quite different from that observed in seedling of ageotropum pea (Olsen and Iversen 1980a) and in agravitropic mutants of barley (Moore 1985). Transformed roots grown in the vertical position continued to grow vertically, and did not deviate significantly from the direction of gravity, whereas the agravitropic mutants cited above did not maintain a constant orientation with respect to gravity when seedlings were placed in the vertical position.

As shown in Fig. 3, pRi-transformed roots grown in the vertical position showed a pattern of growth (second order polynomial) similar to that of normal roots. At the seedling age chosen for gravistimulation ( $24 \mathrm{~h})$, transformed roots had a slightly higher growth rate (Tab. I). Clearly, these differences in growth rate cannot explain the reduced graviresponse of $\mathrm{pRi}$-tranformed seedling roots since, in lentil, roots with a high growth rate develop a more rapid gravitropic response (Perbal 1973).

We observed striking differences in gravitropism between transformed and control roots. Stimulation at various angles of normal roots was followed by a latent period (Fig. 6, phase I), after which they developed rapid

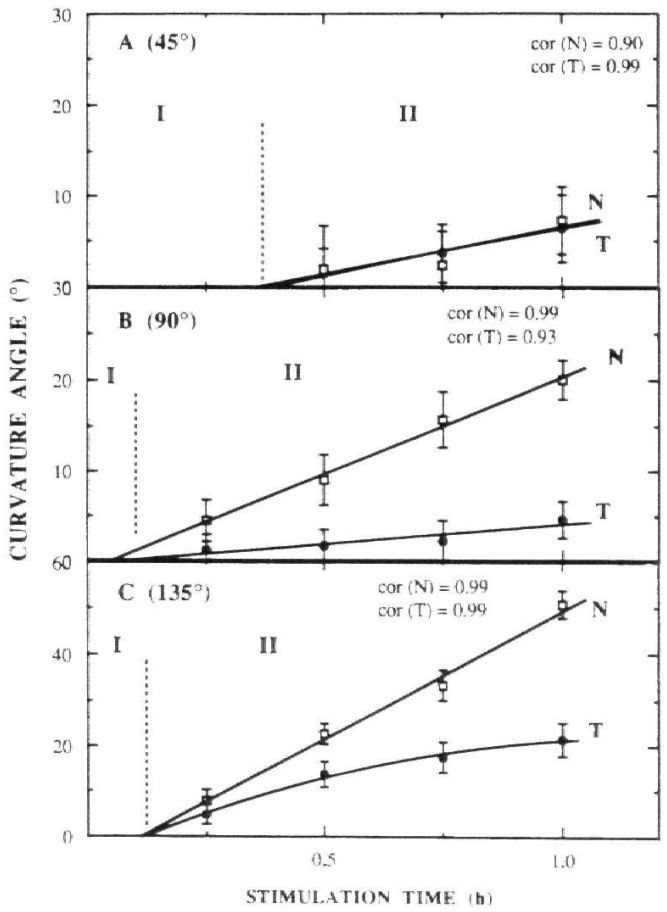

Fig. 6. Determination of the length of the latent phase. Regression lines were calculated for the experimental points of phase II for each response curve during stimulation at (A) $45^{\circ}$. (Bi) $90^{\circ}$ and (C) $135^{\circ}$. The correlation coefficient (cor) is indicated above each regression line. The length of the latent phase (I) was estimated from the regression equations for $y=0^{\circ}$. and were approximately $20 \mathrm{~min}$ at $45^{\circ}, 4 \mathrm{~min}$ at $90^{\circ}$ and $7 \mathrm{~min}$ at $135^{\circ}$ for both $\mathrm{N}$ and $\mathrm{T}$ joots.

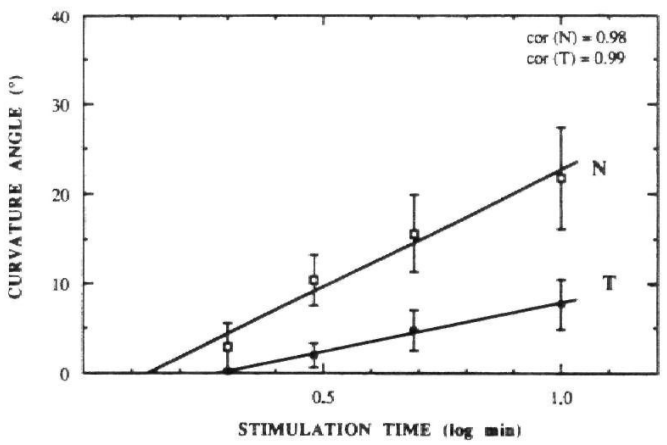

Fig. 7. Presentation time of normal (N) and transformed (T) roots. Seedlings were stimulated at $135^{\circ}$ for the period indicated on the abscissa. and then rotated on a clinostat at $2 \mathrm{rpm}$. Curvature of the roots was determined after $1.5 \mathrm{~h}$. The presentation times were obtained by extrapolation to the log-abscissa of linear regression lines (correlation coefficients were 0.98 for $\mathrm{N}$ and 0.99 for $T$ samples). Vertical bars represent confidence intervals at $P=0.05(\mathrm{n}>30)$. Each value represents $32(\mathrm{~N})$ and 44 (T) seedlings. 
downward curvature in the tip region for $1 \mathrm{~h}$ (Fig. 5, phase II). After this, curvature continued at a lower rate until the root tips were oriented parallel to the direction of gravity (Fig. 5, phase III). Normal roots stimulated at $135^{\circ}$ showed a higher gravitropic response than those stimulated at $90^{\circ}$ or at $45^{\circ}$. The curvature pattern in normal rapeseed roots is similar to that described for other plants. where the optimum angle of stimulation is also $135^{\circ}$ (in cress by Iversen and Rommelhoff 1978, in lentil by Perbal 1978). Compared to normal roots, the rate of curvature in transformed roots during the first hour was the same as that of controls at $45^{\circ}$. but significantly less at $90^{\circ}$ (Fig. 6, phase II). It is of particular interest that in response to continuous stimulation at $135^{\circ}$, transformed roots were able to curve only until their root tips reached the horizontal position ( Fig. 5C), after which they continued to grow horizontally. Thus, even though these roots respond with little curvature during stimulation at $45^{\circ}$ or $90^{\circ}$, they are able to establish a curvature during stimulation at $135^{\circ}$.

The altered gravity responsiveness of stimulated transformed roots may result from a modification of one or several steps in gravitropism, such as perception, signal transduction, signal transmission. or competence of elongating target cells. The latent time, which is the time between stimulus and response and which reflects the timing of downstream events of the response, was determined by extrapolation of a regression line of the initial phase of curvature (phase II in Fig. 5; Fig. 6). For each angle of stimulation, the latent time was similar in normal and in transformed roots, which suggests that the timing of response events was not modified.

In order to compare the sensitivity to gravity of transformed and normal roots. we analyzed the presentation time, which defines the minimal period of stimulation necessary to obtain a gravitropic response (Johnsson and Pickard 1979). This analysis showed that $120 \mathrm{~s}$ were required to induce curvature in transformed roots, while normal roots were able to curve after $80 \mathrm{~s}$ of stimulation. Since this parameter of sensitivity is correlated with the rate of sedimentation of amyloplasts involved in the perception of gravity (Volkmann and Sievers 1979. Sack et al. 1985), our results suggest that the reduction of gravitropic reaction in pRi-transformed roots could be associated with a modification in the displacement of amyloplasts in the statocytes.

Thus, the gravitropic behavior of transformed roots could be explained, at least in part, by modification of the systems determining sensitivity to gravity. Another possibility would be that the lateral transport of the inhibitor responsible for curvature (Shaw and Wilkins 1973) might occur as in the controls, but the message from the cap might be insufficient to induce rapid downward curvature. Recently, certain authors have proposed that gravitropic bending is also the consequence of changes of sensitivity to auxin (Evans 1991). Thus, in transformed rapeseed the elongating cells responsible for gravitropic bending might present a different reactivity to auxin. which could alter the competence of these cells to respond to gravity. The transformed roots studied here contain both aux and rol genes, of which the former could be responsible for changes in auxin content, while the latter have been shown to modify the sensitivity of root cells to auxin (Shen et al. 1988, 1990).

The studies described here are the first steps in the characterization of the growth and graviresponse of rapeseed roots transformed by pRi TR- and TL-DNA. This material is now being used to study other aspects of the graviresponse, including detailed studies of cap ultrastructure and of movement of amyloplasts during stimulation, as well as of auxin levels and sensitivity. Transformants expressing individual pRi T-DNA genes or small groups of genes will also soon be ready for characterization and should help clarify the relationship between specific gene functions and the developmental modifications observed.

Acknowledgments - This work was supported by the Centre National des Etudes Spatiales rConvention 0242h.

\section{References}

Ackermann. C. 1977. Pflanzen aus Agrobacterium rizogenes Tumoren an Nicotiana Jabacum. - Plant Sci. Lett. 8: 23-30.

Amselem. J. \& Tepfer. M. 1992. Molecular basis for novel root phenotypes induced by Agrobacterium rhizogemes A4 on cucumbers. - Plant Mol. Biol. 19: 421-432.

Barlow, P. W. \& Hofer, R. M. 1982. Mitotic activity and cell elongation in geostimulated roots. - Physiol. Plant. 54: 137$1+1$.

Capone. I.. Spano, L.. Cardarelli, M.. Bellincampi. D.. Petit. A. \& Costantino. P. 1989. Induction and growth properties of carrot roots with different complements of Agrobacterium rhi-ogenes T-DNA. - Plant Mol. Biol. 13: 43-52

Chilton. M. D.. Tepfer. D. A., Petit, A.. David, C.. CasseDelbart. F. \& Tempé. J. 1982. Agrohacserium rhiogenes inserts T-DNA into the genome of host plant root cells. Nature 295: 432-434

Cholodny, N. 1928. Beiträge zur hormonalen Theorie von Tropismen. - Planta 6: 118-133.

Church. G. M. \& Gilbert. W. 1984. Genomic sequencing. Proc. Natl. Acad. Sci. USA 81: 1991-1995.

Darbelley. N. \& Perbal. G. 1984. Modèle de différenciation des cellules corticales de la racines de Lentille. - Biol. Cell. 50: $87-92$.

Dellaporta, J. L., Wood, J. \& Hicks, J. B. 1983. A plant DNA minipreparation: version II. - Plant Mol. Biol. Rep. 1: 19-21.

De Paolis, A.. Mauro, M. L.. Pomponi, M.. Cardarelli. M.. Spano. L. \& Costantino, P. 1985. Localization of agropine synthesizing functions in the TR regions of the root inducing plasmid of Agrobacterium mizogenes 1855. - Plasmid 13: $1-7$

Driss-Ecole. D. Cottignies. A.. Jeune. B.. Corbineau. F. \& Perbal. G. 1994. Increased mass production of Veronica arvensis grown on a slowly rotating clinostat. - Environ. Exp. Bot. Med. (In press).

Evans, M. L. 1991. Gravitropism - interaction of the sensitivity modulation and effector redistribution. - Plant Physiol. 95: $1-5$

Feinberg, A. P. \& Vogelstein. B. 1983. A technique for radiolabeling DNA restriction fragments to high specific activicy. Anal. Biochem. 132: 6-13

Firn, R. D. \& Digby, J. 1980. The establishment of tropic curvature in plants. - Annu. Rev. Plant Physiol. 31: 131148. 
Guerche, P., Jouanin, L., Tepfer, D. \& Pelletier, G. 1987. Genetic transformation of oilseed rape (Brassica napus) by the $\mathrm{Ri}$ T-DNA of Agrobacterium rhizogenes and analysis of inheritance of the transformed phenotype. - Mol. Gen. Genet. 206: $382-386$.

Ishikawa, H.. Hasenstein, K. H. \& Evans, M. L. 1991. Computer based video digitized analysis of surface extension in maize roots. - Planta 183: 381-390.

Iversen, T. H. \& Rommelhoff, A. 1978. The starch statolith hypothesis and the interaction of amyloplasts and endoplasmic reticulum in root geotropism. - J. Exp. Bot. 29: 1319 1328.

Jackson, M. B.\& Barlow, P. W. 1981. Root geotropism and the role of growth regulators from the cap: a re-examination. Plant Cell Environ. 4: 107-123.

Jouanin. L. 1984. Restriction map of an agropine-type Ri plasmid and its homologies with Ti plasmid. - Plasmid 12: $91-102$

- . Vilaine. F. Tourneur, J.. Tourneur. C.. Pautot. V.. Muller, J. F. \& Caboche, M. 1987. Transfer of a $4.3 \mathrm{~kb}$ fragment of the TL-DNA of Agrobacteriam rhizogenes strain A 4 confers the pRi transformed phenotype to regenerated tobacco plants. Plant Sci. 53: 53-63.

Johnsson. A. \& Pickard, B. G. 1979. The threshold stimulus for geotropism. - Physiol. Plant. 45: 315-319.

Kiss. J. Z. Hertel, R. \& Sack. F. D. 1989. Amyloplasts are necessary for full gravitropic sensitivity in roots of Arabidopsis thaliana. - Planta 177: 198-206.

Klemmer. R. \& Schneider, H. A. N. 1979. On a blue light effect and phytochrome in the stimulation of georesponsivness of maize roots. - Z. Planzenphysiol. 95: 189-197.

Mirza. J. I., Olsen. G. M.. Iversen. T.-H. \& Maher. E. P. 1984. The growth and gravitropic responses of wild type and auxin-resistant mutants of Arabidopsis thaliana. - Physiol. Plant. 60: 516-522.

Moore, R. 1985. A morphometric analysis of the redistribution of organelles in columella cells in primary roots of normal seedlings and agravitropic mutants of Hordeum vidgare. - J. Exp. Bot. 36: 1275-1286

Murashige. T. \& Skoog. F. 1962. A revised medium for rapid growth and bio assays with tobacco tissue cultures. - Physiol. Plant. 15: 473-497.

Olsen. G. M. \& Iversen. T.-H. 1980a. Growth and curvature in seedlings of Pisum sativum and an ageotropic mutant. Physiol. Plant 50: 269-274

- \& Iversen. T.-H $1980 \mathrm{~b}$. Ultrastrusture and movements of cell structures in normal pea and an ageotropic mutant. Physiol. Plant 50: 275-284.

Perbal. G. 1973. Etude de la relation entre la vitesse de croissance des racines du Lens culinaris L. et leur courbure géotropique. - C. R. Acad. Sci. Ser. III 276: 745-748.

- 1978. La perception et la réaction gravitropiques des racines. - Bull. Soc. Bot. Fr. 125: 335-364.

Pilet. P. E. \& Ney. D. 1981. Differential growth of georeacting maize roots. - Planta 151: 146-150.

Rivier. L. \& Pilet. P. E. 1974. Indolyl-3-acetic acid in cap and in apex of maize roots: identification and quantification by mass fragmentography. - Planta 120: 107-112.

Sack, F. D., Suyemoto, M. M. \& Leopold. A. C. 1985. Amyloplast sedimentation kinetics in gravistimulated maize roots. - Planta 165: 295-300.

Saether. N. \& Iversen, T.-H. 1991. Gravitropism and starch statoliths in an Arabidopsis mutant. - Planta 184: 491-497.

Schmülling, T., Schell, J. \& Spena, A. 1988. Single genes from Agrobacterium rhizogenes influence plant development. EMBO J. 7: 2621-2629.

Selker. J. M. L. \& Sievers, A. 1987. Analysis of extension and curvature during the graviresponse in Lepidium roots. - Am J. Bot. 74: 1863-1871.

Shen, W. H., Petit. A.. Guern. J. \& Tempé. J. 1988. Hairy roots are more sensitive to auxin than normal roots. - Proc. Natl Acad. Sci. USA 85: 3417-3421.

- Davioux. E., David, C., Barbier-Brygoo, H., Tempé, J. \& Guern. J. 1990. High sensitivity to auxin is a common feature of hairy roots. - Plant Physiol. 94: 554-560.

Shaw. S. \& Wilkins, M. B. 1973. The source and lateral transport of growth inhibitors in geotropically stimulated roots of Zea maxs and Pisum sativam. - Planta 109: 11-26.

Spano, L.. Pomponi. M., Costantino, P., Van Slogteren. G. M. S. \& Tempé. J. 1982. Identification of T-DNA in the rootinducing plasmid of the agropine-type Agrobacterium rhizogenes 1855. - Plant Mol. Biol. 1: 291-300.

- Mariotti. D.. Pezzoti. M.. Damianin. F. \& Arcioni. S. 1987. Hairy roots transformation in alfalfa (Medicuge sativa L). Theor. Appl. Genet. 73: 523-530.

Tepfer, D. 1984. Transformation of several species of higher plants by Agrobacteritum thizogenes: sexual transmission of the transformed grenotype and phenotype. - Cell 37:959967.

- \& Casse-Delbart. F. 1987. Agrobacterim rhizogenes as a vector for transforming higher plants. - Microbiol. Sci. 4 : 24-28.

Volkmann, D. \& Sievers, A. 1979. Graviperception in multicellular organs. - In Encyclopedia of Plant Physiology. New Series. Vol. 7. Physiology of Movements (W. Haupt and M. E. Feinleib, eds), pp. 573-600. Springer-Verlag. Berlin ISBN 3-540-08776-1

Went. F. W. \& Thimann, K. V. 1937. Phytohormones. - Mac Millan. New York. NY.

White. F. F. Taylor. B. H., Huffman. G. A.. Gordon. M. P. \& Nester. F. W. 1985. Molecular and genetic analysis of the transformed DNA regions of the root inducing plasmid of Agrobacterium rhizogenes. - J. Bacteriol. 164: 33-44.

Williams. P. H. \& Hill, C. H. 1980. Rapid cycling populations of Brassica. - Science 232: 1385-1389.

Young, L. M., Evans. M. L. \& Hertel, R. 1990. Correlations between gravitropic curvature and auxin mouvement across gravistimulated roots of Zea mavs. - Plant Physiol. 92: $792-796$

Zieschang. H. E. \& Sievers. A. 1991. Graviresponse and the localisation of its initiating cells in roots of Phleum prasense L. Planta 184: 468-477. 
This document is a scanned copy of a printed document. No warranty is given about the accuracy of the copy. Users should refer to the original published version of the material. 